\title{
A Caribbean evaluation of public versus private drinking water provision: the case of St. Maarten, Netherlands Antilles
}

\section{Marco A.C. Schouten*, Damir Brdjanovic and Meine Pieter van Dijk}

UNESCO-IHE Institute for Water Education, PO Box 3015, 2601 DA Delft,

The Netherlands

E-mail:m.schouten@unesco-ihe.org

E-mail: d.brdjanovic@unesco-ihe.org

E-mail: m.vandijk@unesco-ihe.org

*Corresponding author

\begin{abstract}
This article assesses how a small island state can choose the best option in the process of private sector involvement. It reviews the decision process to involve or not the private sector in water and sanitation supply and in which way. Nine criteria are used to make the choice. A careful weighing process is necessary, taking the history into account, looking at the special institutional situation in the country and involving the stakeholders, and even then there is no guarantee of success! An existing public utility may be better placed to look after the modernisation and extension of the water and sanitation system than a new private firm.
\end{abstract}

Keywords: private water supply; Netherlands Antilles; competitive bidding; evaluation

Reference to this paper should be made as follows: Schouten, M.A.C., Brdjanovic, D. and van Dijk, M.P. (2008), 'A Caribbean evaluation of public versus private drinking water provision: the case of St. Maarten, Netherlands Antilles', Int. J. Water, Vol. 4, No. 3/4, pp.258-274.

Biographical notes: Marco Schouten is a Senior Lecturer at UNESCO-IHE, the Institute for Water Education at Delft, The Netherlands. He has conducted research in the areas of business administration and policy development primarily in the water services sector, and has published in several journals, including water policy and international environmental agreements.

Damir Brdjanovic is an Associate Professor of urban sanitation at UNESCO-IHE, the Institute for Water Education at Delft, The Netherlands. He holds $\mathrm{PhD}$ and MSc degrees. He has conducted research on sanitation systems in different parts of the world and published extensively.

Meine Pieter van Dijk is an Economist and Professor of Water Services Management at UNESCO-IHE Institute for Water Education in Delft and Professor of Urban Management at the Institute of Social Studies in The Hague, both in The Netherlands. He received his $\mathrm{PhD}$ in Economics from Free University Amsterdam. He is member of the research schools CERES and SENSE. His recent books are Managing Cities in Developing Countries, the Theory and Practice of Urban Management (2006, Cheltenham: Edgar Elgar) and with C. Sijbesma (eds, 2006) Water and Sanitation Institutional Challenges in India (New Delhi: Manohar). 


\section{Introduction}

Caribbean water supply and sanitation services are lagging behind and the island governments are exploring possibilities to substitute the traditional local providers of water services by private companies, hoping this would bring an additional impetus to the service provision. However, the involvement of private parties in the provision of water services is surrounded with controversy. Apart from a history of mixed results achieved by newly appointed private operators, there is a general lack of understanding how private management of water service provision compares to public management, given the many restrictions and regulations surrounding water provision.

This article aims to give further insight to how operators with different ownership characteristics compare. In order to make this comparison use is made of a case study located on the Caribbean island of St. Maarten. In this case one public and one private party compete to be given the opportunity to manage and extend the water services at the island for the coming 10 years. The authors' involvement as independent evaluators, and the permission of the government to use the case for scholarly purposes, benefited the research greatly in terms of access to full information and gaining inside knowledge. The collected information is formatted in this article to assess in a structured manner the differences between both parties' intended strategies to manage the service provision.

The article is structured in the following manner. First, the background is given with respect to the ongoing trend to involve private parties in the Caribbean water sector. The next paragraph zooms into the specific context and developments at the island of St. Maarten. The decision process leading towards (possible) private sector involvement is reviewed in detail. Then, after the introduction of an analytical framework, the actual comparison is presented between both parties. The article concludes by making some final comments related to the case description.

\section{Caribbean governments exploring private sector involvement}

Due to their small sizes, lack of natural water storage and their vulnerability to natural and anthropogenic hazards including drought, cyclones and urban pollution, the Caribbean islands are coping with fragile and scarce water resources and insufficient water infrastructure (World Bank, 2005a). Hence, Caribbean governments are continuously challenged to come up with, and apply, both innovative solutions for funding and managerial arrangements in order to provide and maintain sustainable water services provision. Therefore, the full commitment of the Caribbean region to Agenda 21, the Barbados Programme of Action, the Pacific-Caribbean Joint Programme for Action on Water and Climate, the World Summit for Sustainable Development Plan of Implementation and the UN Millennium Development Goals, is prerequisite to ensuring better and affordable water supply and sanitation services by 2015 . The 4th World Water Forum held in Mexico City served as an opportunity for small Caribbean island states and territories to seek international support to increase their self-reliance and self-sustainability regarding water supply and sanitation services.

Private sector involvement as an innovative way to attain sustainable water service provision has been popular amongst Caribbean governments. Several examples can be identified of private sector involvement in the water sector (Pinsent Masons, 2006); of which probably the most famous one is the contract of Puerto Rico due to the 
extensive media coverage. In 1995, the Puerto Rico Aqueduct and Sewer Authority (PRASA) signed a management contract with Veolia which lasted 7 years. After a critical assessment of its performance, Veolia was replaced by another private operator (Suez). Suez signed a 10-year operations and maintenance contract, but again the contract with this private party was prematurely terminated in 2004. Currently the public authorities of Puerto Rico are resuming the responsibility for the management of water and sanitation services on the island. Another well-known example is the 50/50 joint venture between Aguas de Barcelona and the Cuban government, dating from 1999. The joint venture is serving a total of 1.8 million people in Havana with a contract duration of 25 years. Also in Trinidad and Tobago a joint venture was established between Severn Trent, WASA and the government of Trinidad and Tobago. This contract was supported by a US\$ 80 million loan from the World Bank, and ended in April 1999. The Dominican Republic signed, in the year 2001, two service contracts with private parties for the installation of metres, metre reading, billing and collection, one for the eastern and one for the western part of its service area in Santo Domingo. The contract for the western part was awarded to the Colombian company AAA, which increased the share of metering from $1 \%$ to $25 \%$ and increased collected revenues by $128 \%$ in less than 2 years. Examples of Build Operate Transfer (BOT) type of contracts can be found on the British Virgin Islands, the Cayman Islands and the Bahamas.

The major reason for the relatively high degree of private sector involvement in the Caribbean region compared to other regions is that a lot of Caribbean islands experience difficulties in keeping pace with the claims that economic development places on the infrastructure of the island (UNEP, 1999). The Caribbean has succeeded over the past decades in realising a sustained growth in per capita incomes, with most of them becoming middle-income countries and achieving high levels of economic development. The average growth in GDP per capita over the last 40 years equals for a median Caribbean country is $2.8 \%$ higher than Latin America in every decade (World Bank, 2005a). Yet, currently the abiding impression is one of concerns for the sustainability of the past accomplishments. The most important asset that brought about the economic development, being the beauty of the natural environment, is severely under threat. The quotation 'Beauty is a fragile gift' from the Roman poet Publius Ovidius Naso (43 BC) more than 2000 years ago, seems in this respect all the more relevant to the Caribbean islands in the present day.

The explosive increase of tourism and its accompanying economic growth has resulted in an increased demand for larger coverage and better quality of utility services (Brdjanovic and Gijzen, 2005). Population at the islands have experienced in the last decade an explosive increase, resulting in increased migration to, and expansion in, urban zones against a backdrop of poor urban planning, leading to greater consumption, and thus, increased waste generation. Most infrastructure required to deal with the consequences of economic development is lagging behind. Especially sewerage networks are insufficiently developed as large parts of the population are not connected, and wastewater is often inadequately treated prior to discharge, which can cause health problems as well as environmental damage. Owing to the relatively hilly area in many island states, the distribution system is hydraulically complex, although relatively small. There are seasonal peaks in demand to be coped with, coinciding with the peak in hotel occupancy and the end of the dry season (World Bank, 2005b). Despite its urgency for change, a common denominator with respect to service provision (especially wastewater services) is the local population's insufficient awareness of the need for environmental 
protection and conservation, and this lack of awareness is one of the main reasons that governments unfortunately often do not consider remedial actions as a priority.

Another reason for the high degree of private sector involvement is the attractiveness of the region for private parties. The region contains many densely and rapidly growing urbanised areas with sufficiently large middle classes to attract private operators. The attractiveness for private parties to get involved into the service provision in the Caribbean is strengthened by the favourable conditions imposed by international financial institutions with loan (re-)negotiations and structural adjustment programmes.

A final reason why the Caribbean islands have a high degree of private sector involvement relates to the scarcity at the island states of adequate human resources. The small size of the islands creates a problem for responsible governments and local service providers to access adequate human capacity, skills and financial resources. External introduction of knowledge and skills by outsiders (foreign private parties) might bring the necessary human and financial resources to the island.

\section{Comparing public versus private water services provision}

The issue whether civil servants or private companies are better suited to provide water supply and sanitation services has a long history. Crain and Zardkoohi (1978) refer even back to debates in 1850 over nationalising certain British enterprises. Until now, it has not been possible for the scientific community to make general statements how involving the private sector implicates the conduct and performance of a water service provider (Brown and Iverson, 2004). Decades of research on the determinants of the success of water operators have not resulted in conclusive evidence whether private sector involvement indeed fulfils its objectives. Vickers and Yarrow (1991, p.117) reviewing empirical studies of performance differences between public and private utilities with natural monopoly elements, like water, concluded:
"the results of empirical studies are very mixed: some give the advantage to public ownership, others to private ownership and yet others can find no significant difference between the two. Substantial performance differences among utilities do, nevertheless, exist, both within and between countries".

Several factors attribute to the complexity of assessing properly the impacts of private sector involvement in the water sector in comparison to public services provision.

\subsection{Defining performance}

What is the performance of a water provider? The answer to this question is not easy to come by, but is an essential one if a meaningful comparison is to be made. Interpreting performance is problematic since there is no universally recognised measure of this concept, forcing to make use of a selection of performance indicators. However, the relevance of any indicator may vary from utility to utility depending on the local circumstances.

\subsection{Situational dependence}

Much research on the relation between ownership and performance compare a data set of a group of utilities where the operators are privately owned, with a set of data from 
another group of utilities where the operators are publicly owned. However, it is very hard to find a way to make a meaningful comparison between one water services provider and another, as its operations have such large and diverse characteristics and implications. Water utilities vary along dimensions aside from organisational form. They differ by factors such as size and dispersion of the population served; in the scale and age of their capital equipment; in costs paid for labour, machinery, water, energy and finance; in the quality of available water supplies and in how much they treat the water before pumping it to customers. Since some of these features might differ systematically as between public and private water utilities, it would likely be misleading simply to divide the water suppliers into 'public' and 'private', to find the two average costs, and to attribute whatever difference there is to ownership effects (Donahue, 1989).

\subsection{Assuming a direct relationship between operator's ownership and performance}

Although studies about the linkage between public versus private operation and performance levels provide a valuable start in understanding linkages, they are based on the assumption that the ownership of the operator has an independent and direct impact on performance. A deficiency in this type of research is that it fails to elaborate on the source and strength of this impact. Most scholars and practitioners seem to accept it as given that operators with different ownership characteristics have a different way of managing the service provision (Ward et al., 1995).

\subsection{Uniqueness of the water sector}

Many scholars find that private sector involvement is superior compared to public sector operations, basing themselves on a body of literature mostly derived from other sectors. Indeed, in other sectors researchers have produced 'mounting evidence' (Jerome, 2004, p.1) that associates private sector involvement with improved performance, higher profitability, output and productivity growth, fiscal benefits and better access for the poor. The mounting evidence, Jerome is referring to, is based on studies executed by several authors (for example Megginson et al., 1994; Boubakri and Cosset, 1998; Dewenter and Malatesta, 2001). However, the unique combination of the water sector as monopolistic, industrial and providing an essentially public good cannot be found in, and prevents duplication from, other sectors. Pargal (2003, p.23) based on an econometric assessment of private investment flows and data from Latin America concludes that:

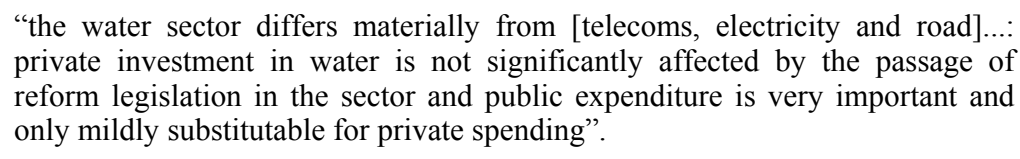

In sum, due to specificities of the water sector a comparison of performance of water operators with different ownership characteristics is cumbersome. In this respect the article at hand suggests an alternative approach. Instead of comparing different utilities, with all the complications of each utility having its' own unique circumstances, the article uses one and the same case in which public and private (intended) water service provision is to be compared. Also the difficulty to arbitrarily identify 'performance' is avoided, by focussing instead on the (intended) conduct of both parties. The case entails the 
comparison of the intended strategies of both a private and a public party to provide water services for the coming 10 years to the population of St. Maarten. Both parties made their intentions explicit in their bids to the island government. Hence, the main question to which the case study seeks an answer is: how do public and private parties compare in their intentions towards managing water services?

\section{The St. Maarten case study}

St. Maarten is one of the five islands that form The Netherlands Antilles, which in turn is a part of the Kingdom of The Netherlands. The local government of St. Maarten has the authority to handle the most vital functions; however, they cannot conflict with the laws of the Dutch Antilles or The Netherlands. The island is located approximately 280 miles east of Puerto Rico (see Figure 1).

Figure 1 Map of St. Maarten/St. Martin (see online version for colours)

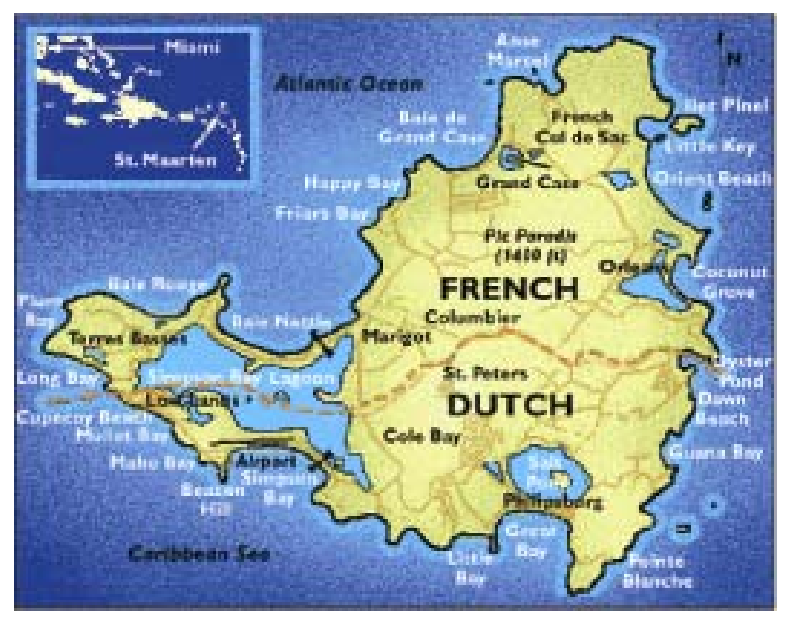

St. Maarten/St. Martin is a blend of two European cultures, namely the French and the Dutch, set in the Caribbean. The island of St Maarten has an interesting historical background; Christopher Columbus discovered St. Maarten in 1493, on the Patron Saint Day of St. Martin of Tours, and in the 140 years that followed, it changed flags many times. The Spanish, French, Dutch and English all claimed possession in 1648, when the island was divided in two by the Treaty of Concordia, which was signed on 23 March 1648. The Dutch received 16 square miles and the French received 21. St Maarten, with its capital Philipsburg, occupies the southern part of the island's 16 square miles. Today, the inhabitants of this friendly island are proud of their 350-year coexistence and have never constructed an official border, having only a symbolic border between the island's two countries. There is no border control between the two parts of the island; there is free access and movement between the two countries and border signs indicate the entrance from one side to the other. The French part of the island, St. Martin, is out of the scope of the case study as it separately governed and its water services are also separately organised. 
The island of St. Maarten is exemplary for the larger developments in the region. Also St. Maarten has enjoyed over the last few decades a tremendous economic growth. Annually almost 1.3 million tourists visit the island. This total includes both tourists on cruise ships and those who actually sleep on the island. The boom in tourism on the island in the 1990's resulted in an explosive growth in population. At the last census count in 2000, the population of Dutch part St. Maarten was around 43,000 people, made up of almost 100 nationalities, very much in contrast with the situation in 1960 when it counted only 3000 inhabitants.

Although the government has acknowledged the need for mitigating measures in establishing a proper infrastructure to keep up with the rapid growth of the population, it has been rather slow in realising this. The water services are put under the responsibility of different parties in the following manner, obstructing to attain the benefits from an integrated water cycle approach.

1 Drinking water treatment: The island relies for its drinking water treatment on a reverse osmosis membrane plant with a maximum production capacity of 13,500 $\mathrm{m}^{3} /$ day which desalinates seawater. Although this plant is owned by the government, a 10-year operation and management contract was signed in 1997 with a subsidiary of the French multi-national Veolia.

2 Drinking water distribution: Drinking water distribution has been the responsibility since 1970 of a publicly owned multi-utility, which has been responsible for both electricity and drinking water distribution for the Dutch part of St. Maarten. The company procures the treated water from the operator of the desalination plant, distributes it and collects the water tariff from the customers.

3 Sewage collection: Although the majority of St. Maarten is unsewered, there is a limited sewage system at the island. The current number of house connections is estimated to be around 1000, mainly within the areas of the capital Philipsburg and a few other locations. The government of St. Maarten owns the sewage facilities, but the sewage collection operations are outsourced via a management contract to a local private contractor.

4 Storm water collection: In the tropical climate of St. Maarten, heavy rains and storms are common. Sometimes hourly and daily precipitation at some locations can be as much as 150 and $600 \mathrm{~mm}$, respectively! Due to the small size of the island and its steep slopes, it does not take long until this mixture reaches beaches facing the open sea, seawater lagoons, fresh water ponds or brackish inland water ponds. It is currently impossible to estimate where the environmental effect is greatest, especially in relation to the water quality. It could be on the bathing waters of the picturesque beaches, on the surrounding coral reefs that provide a habitat for marine life (including the legally protected turtles), on the fragile ecosystem which hosts a number of rare bird species or maybe on the already heavily polluted waters of one of the ponds of the island.

5 Sewage treatment: The total capacity of the wastewater treatment facilities at St. Maarten is approximately 5000-6000 population equivalent (p.e.), covering an approximate $15 \%$ of the total demand. Besides these, there are several private package plants owned by hotels. The majority of plants are activated sludge plants, and some employ attached-growth systems (such as Rotating Biological Contactors). 
In general all the plants perform poorly. According to current practice, limited attention is paid to sludge treatment; the largest treatment plant has some provision for sludge drying, while the other plants have no sludge-related facilities whatsoever. The package plants associated with the hotels are not under the jurisdiction of the island government and are operated and controlled by the hotels themselves. Laboratory facilities are limited and poorly equipped. Furthermore, there are no wastewater effluent standards or regulations in place, nor is there any sort of continuous monitoring of the surface water quality (Grabowski \& Poort, 1995).

After the destruction in 2000 caused by Hurricane Louis, the existing water infrastructure needed to be urgently rehabilitated. The first action taken by the government, being part of the Kingdom of The Netherlands was to seek financial support from the Dutch government to reconstruct the destroyed sewerage system. Although their request was granted, the Dutch funds could only be disbursed if the island fulfilled several conditions. To satisfy these conditions, the island government hired several consultants to reassess the scope of the project. Based on that assessment the island government became convinced that to thoroughly tackle the water and wastewater problems of the island, it should take the matter in hand much more rigorously. Hence, it got into contact with a private Dutch party that proposed the idea of establishing a joint venture company that would be made responsible to construct and manage a large-scale sewerage system on the island. In principle, the island government positively received this idea although it was hesitant on the distribution of shares in the to-be-established company. Initially it was the intention that the island would only have a minority of the shares. For the private party this affected the feasibility of the project and as compensation it proposed to include also the drinking water provision into the scope of the to-be-established company. In this way important synergies could arise that would make the project feasible.

The inclusion of the drinking water provision in the scope of the project proved to be an important landmark in the decision process. A major actor in the St. Maarten community, the monopolistic electricity and drinking water provider, became involved. This public company and its employees, who were united in a trade union, did not care much for splitting off the drinking water activities to a foreign Dutch company and requested the opportunity to make a counter offer. The island government again was open to this suggestion and asked both parties, the Dutch private party and the local electricity and drinking provider, to make a final bid. The government made the public interest at stake explicit by defining what it expected from the winning party (see Box 1).

Although the foreign private party was not amused by the inclusion of another party in the tendering process, both parties honoured the request and on 31 May 2002 new proposals were submitted. It took until October 2004 to approve the funding and the appointment of the independent evaluator to conduct the evaluation of the two proposals. Based on the independent evaluation of the two bids the island government would make its decision. Once the evaluation was concluded in 2005 the conclusion was clear. Both parties did not manage to put a convincing proposal on the table although in comparison the proposal of the local public electricity and drinking water provider was the least weak one. Based on that conclusion, the island government has entered - and at the moment of writing still is - negotiations with the local public electricity and drinking water provider how to best include the responsibility for extending and managing the water and sanitary services to the St. Maarten population. 


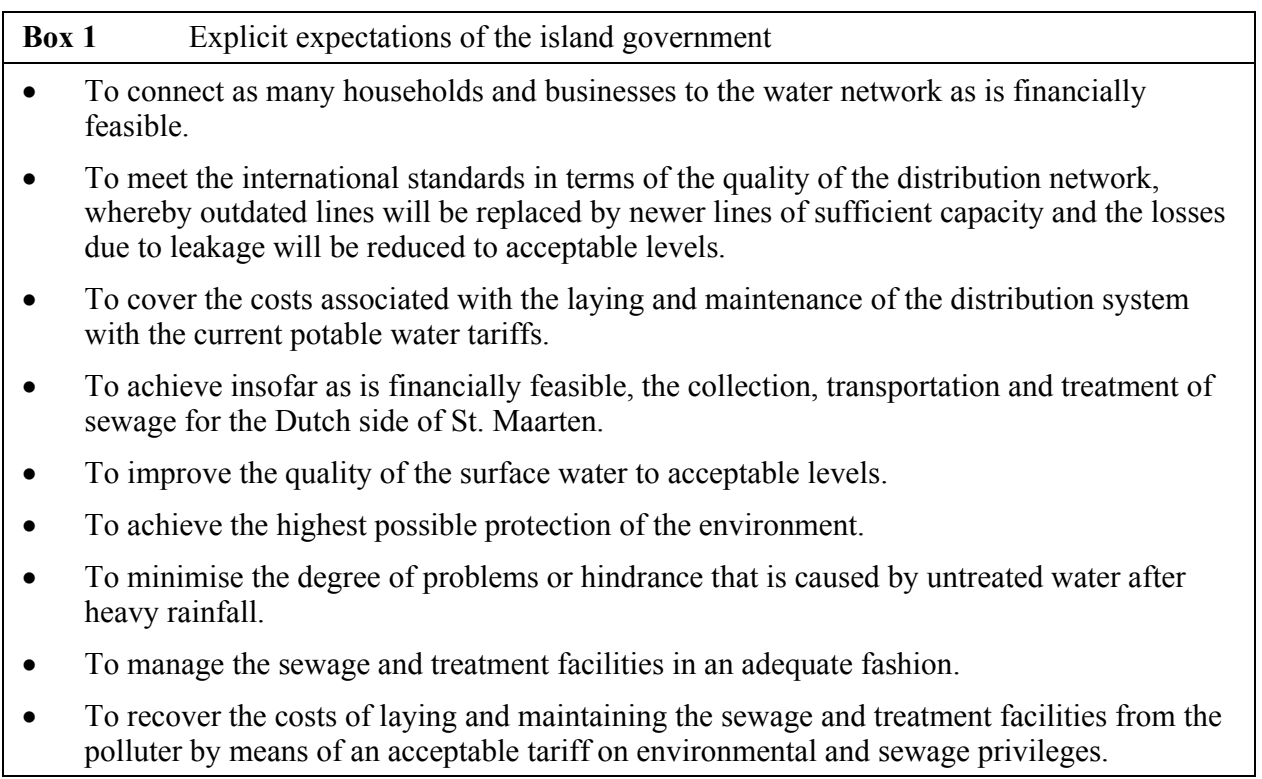

\section{Comparing the parties' strategies}

The bidding documents submitted by both the public party and the private party provide the basis for comparing how both parties compare with respect to their intended strategies for service provision. Although the public party was evaluated as the better one in the evaluation procedure, this does not surface well how both parties compared in their intentions towards service provision. The evaluation was carried out on the basis of a preset of ten evaluation criteria, each having a different weight (Brdjanovic et al., 2005). As the evaluation criteria, which were predefined by the island government, were conceptualised on the basis of the policy priorities of the island, they can only partly support a comparison of the intentions of both bidders in terms of conduct. To structure the comparison of the intended strategies use is made of the distinction Boyne and Walker (2004) have made in the following five types of strategic actions that public service organisations may have:

1 the clients the party wants to serve

2 the products or services the party wants to offer

3 the management of costs and revenues of the operations

4 the internal organisation of the operation of services

5 the external relations the party wants to engage in.

Table 1 divides the evaluation criteria, as set by the island government along the above five strategic actions of Boyne and Walker. In the analysis for each strategic action, first the expectations and constraints given by the government (based on the tendering document) will be described, before the intentions of both parties are compared. These governmental requirements might limit the discretion of the bidding parties in their 
intentions. Hence, the first issue to be identified in the analysis of each strategic action is the extent to which the bidding party is limiting itself by responding strictly to governmental references, or whether it allows itself to pursue ideas of its own. The second issue to be compared is the extent to which one bidder's intentions can be identified as conservative or opportunistic. Does the party intend to make use of innovative, risky strategies to achieve its objectives, or does it rely on established technology and practices? The two issues (reactor-like and prospector-like) reflect the two continuums forming the basis of the typologies of Miles and Snow (1978) to distinguish strategic typologies. The two questions are related to each other, i.e. a company can be reactive but conservative, or reactive but opportunistic. Also the party can be non-reactive but conservative, and vice versa.

Table 1 Evaluation criteria categorised along the strategic actions of Boyne and Walker

\begin{tabular}{|c|c|}
\hline Strategic action & Tendering evaluation criteria \\
\hline Customers & - The degree of coverage of water and sewer connections \\
\hline Products/services & $\begin{array}{l}\text { - The drinking water and wastewater services delivered } \\
\text { - The amount of water distributed (water treated minus Unaccounted for } \\
\text { Water) }\end{array}$ \\
\hline Cost/revenues & $\begin{array}{l}\text { - The investment costs } \\
\text { - The financing arrangements for investment, including donor financing } \\
\text { - } \quad \text { The return on investment and solvency } \\
\text { - } \quad \text { The charges to the customers }\end{array}$ \\
\hline $\begin{array}{l}\text { Internal } \\
\text { organisation }\end{array}$ & $\begin{array}{l}\text { - The degree in which use is made of local resources } \\
\text { - The levels of synergy } \\
\text { - The degree to which consideration is given to the interests of } \\
\text { personnel currently involved with sewage collection and treatment, } \\
\text { and potable water distribution facilities } \\
\text { - The legal organisation for the execution of the project as well as the } \\
\text { responsibility for, and authority and control over, the execution }\end{array}$ \\
\hline $\begin{array}{l}\text { External } \\
\text { organisation }\end{array}$ & $\begin{array}{l}\text { - The conditions that are being demanded of the island government to } \\
\text { guarantee the successful execution of the project }\end{array}$ \\
\hline
\end{tabular}

\subsection{The clients the party wants to serve}

The government instructed both parties to connect as many households and businesses to the water and sewerage network as financially feasible. The government did not set a minimum or a maximum number of customers to be connected, and left this to the bidding parties to propose.

Coverage: The differences between the two proposals were very small related to the total numbers of customers they intended to connect to the water and sewerage network. Both parties, used available population growth statistics and reference documents (Grabowski \& Poort, 1998), and based on these they identified the number of people to be connected to the water and sewerage networks. The proposed number of connections to the drinking water network after 10 years is almost identical $(15,000$ for the private party versus 15,060 for the public party). Also the figure for inhabitant's equivalent to be 
sewered after 10 years was close $(65,700$ for the private party versus 64,000 for the public party). Hence, although the government left the total number of people to be connected to the water infrastructure relatively open, both parties were similar in their response.

However, a major difference between both parties was the speed in which the new customers were to be connected. The private party aimed to connect and construct as many connections as soon as possible, while the public local party stretches the construction work evenly over the entire 10-year-period. A clear motivation for the private party to quickly connect new customer, is that such creates an immediate income stream from these new customers, strengthening the financial viability of the proposal. The public party apparently did not perceive such pressure. Hence, the private party can be assessed as more aggressive in its intentions in view of its strategy to connect people quickly to the network.

\subsection{The products and services the party want to offer}

The government explicitly asked within the terms of reference to meet the international standards in terms of the quality of the infrastructure facilities. The technology to be used to reach these required levels was left to the discretion of both parties to propose. Next, it also requested the bidders to reduce the losses due to leakage to acceptable levels.

The drinking water and wastewater services delivered: The differences between both parties were marginal. For drinking water, both parties relied on the same desalination plant to produce drinking water. Related to wastewater services provision, both parties based themselves on consultancy reports which were years before submitted to the island government. Within these reports several recommendations were included which were all adopted by both the bidders. Related to sewage collection and treatment aspects, both parties planned to use the same technology for wastewater collection (separate gravity sewers), and for wastewater treatment (an activated sludge $\mathrm{Carousel}^{\circ}$ ). Hence, although there was sufficient discretion for both parties to be innovative in their intentions, neither of them took this freedom but just relied on earlier made recommendations, possibly tempted by the convenience to save time by using the existing literature.

The amount of water distributed (water treated minus Unaccounted for Water (UfW)): Currently the level of UfW is approximately $25 \%$. Since the treated water is procured from the operator of the desalination plant, the leakages reflect a financial burden and importance is given to reduce the leakage in the distribution network. In this respect, the private party sets a more ambitious goal towards reducing the level of UfW ( $10 \%$ UfW compared to $15 \%$ UfW) and can, hence, be identified as less conservative compared to the public party.

\subsection{The management of costs and revenues of the operations}

The government did not set any requirements on the amount of planned investments of the bidders, although it did set some references with respect to the financing of the operations. The government preset in the tendering documents the level and structure of the water and sewerage tariff for the coming 10 years. Hence, both bidders had no possibility to shape the tariff differently.

The investments: The private party proposed by far the largest investment (US\$ 122 million) over the coming 10 years, almost 70\% more than the public party 
(US\$ 72 million). The reason why the private party required much more investments can be comprehended from the Table 2 given below.

Table 2 Overview of investment by the public and the private party

\begin{tabular}{lcc}
\hline Investment element & Private party & Public party \\
& US\$ & US $\$$ \\
\hline Takeover of existing water infrastructure & 17 million & 0 \\
Takeover of existing desalination plant & 11 million & 0 \\
Additional wastewater facilities & 74 million & 62 million \\
Additional drinking water facilities & 20 million & 10 million \\
Institutional strengthening & 0 & 300 thousand \\
TOTAL & 122 million & 72 million \\
\hline
\end{tabular}

Figure 2 Phasing of investment of the private versus the public party (see online version for colours)

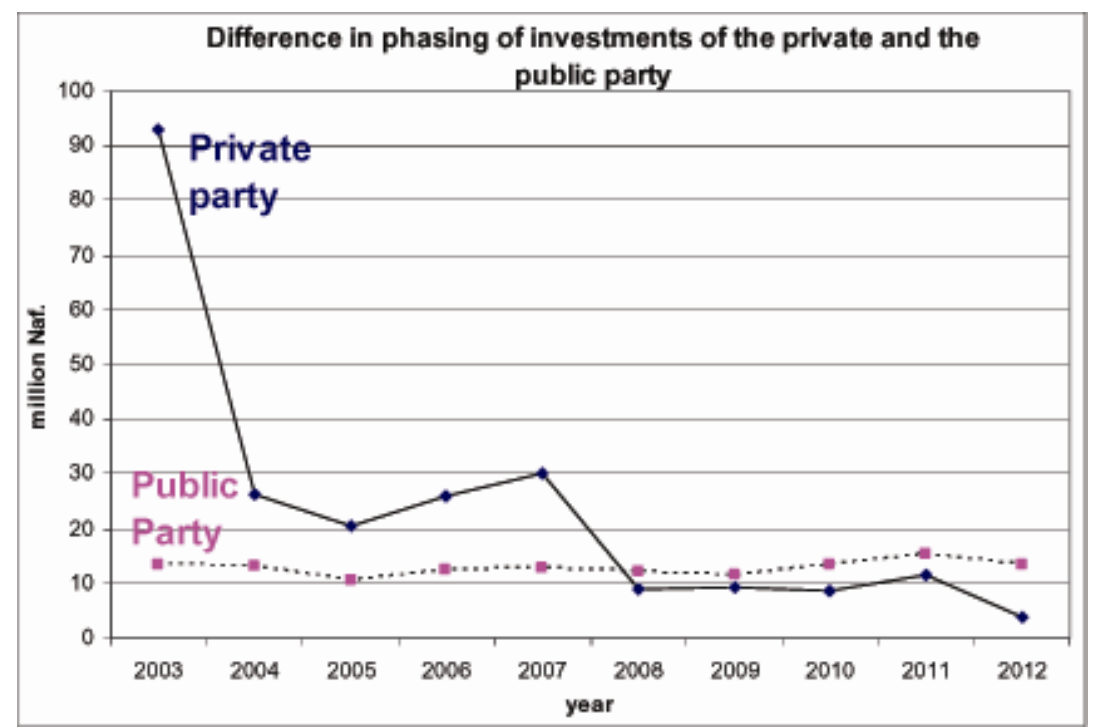

The table shows that although both for drinking water as for wastewater the direct investment of the private party are more compared to the public party's intentions (an additional US\$ 22 million investment), a substantial part of the high investment part of the private company is explained by its the costs associated with taking over the current infrastructure. Since the private party intended to set up a joint venture company which would own the infrastructure it managed, it had to buy the existing infrastructure from the current owners, in contrast to the public party. Also the phasing of the investment was very different the private party proposed to put the focal point of the investment at the beginning of the 10 -year-period, to boost the number of connections as soon as possible, while the public party proposed to spread it more evenly over the same period. Another argument for the private party's investment planning might be the argument to reduce the investment amounts towards the expiry date of the 10-year contract. 
The financing arrangements for investment, including donor financing: Furthermore, the envisaged financing arrangements were conceptually different. The public multiutility would rely mostly on internal cash flow generated from the electricity sales. The foreign private party intended to rely mainly on attracting funds from external parties such as banks and donors. Both parties assumed the availability of the US\$ 27 million as a grant from the Dutch government. An important difference between the two proposals is that in the case of the local multi-utility, such a grant was considered as additional, but the private party relied on this grant to keep the tariffs at an acceptable level and limit the amounts to be borrowed. The different approach of the private party made it more vulnerable compared to the public party in many aspects as follows:

- the private party assumed that it would be able to find sufficient and cheap external funds. Specifically, the major dependence in its proposal on the allocation of a substantial grant was risky

- the private party depended on the government, the contractor of the water treatment plant and even the public multi-utility for the transfer and procurement of the existing assets. If any of these parties were not willing or able to co-operate, it would severely undermine the overall project

- the private party relied on the assumption that it would be able to generate an income stream from connected consumers relatively soon in the project. If there were delays in the implementation schedule, this would create a problem in the financial viability of the overall project

- the public multi-utility had proven its capability in collecting (water and electricity) fees and its willingness to take measures with outstanding debts during its operations on the island. The private party as a newcomer did not have this local experience.

A common conclusion made for both proposals was that water and wastewater will not be a money-maker in the near future in view of the large amounts of investment to be made. The private party can be identified as more ambitious and opportunitistic, in view of its higher and faster investment programme, and its more risky financing arrangement.

\subsection{How does the party intend to internally organise itself?}

The government instructed the bidders to manage the infrastructure in an adequate fashion. However, to define what 'an adequate fashion' entails was left to the bidders. A specific criterion was to what extent the bidder intended to make use of local resources, how it dealt with the current personnel involved, and how it intended to achieve synergetic benefits.

The degree in which use is made of local resources: Both bidders suggest that use will be made of local resources seeking in this respect compliance to the governmental references; although realistically the degree to which both parties succeed in involving local resources largely depends on the availability on the island.

The degree to which consideration is given in the proposal to the interests of personnel currently involved with sewage collection and treatment, and potable water distribution facilities: Compared to the public company, the private company would have a much larger challenge to address issues related to the personnel currently employed. The possibility of a transfer to the newly to-be-established company was one of the major 
reasons for resentment among the employees of the public multi-utility against the foreign private party, and had contributed to the gradual development of a very vocal opposition against involving a company from The Netherlands. The local company's proposal would cause fewer disturbances to current employment levels as most employees would be able to remain with the same employer. It could be anticipated that if the private party were given the project then numerous obstacles in its implementation concerning labour issues would arise.

The levels of synergy: Both parties stated they wanted to achieve synergistic benefits, although the scope to achieve these synergetic savings was different for both bids. The local multi-utility would try to realise them between its electricity operations, its current water distribution operations and the new wastewater operations. The foreign private party would try to establish them between the water treatment, water distribution and the wastewater operations. Not only was the scope different, also the estimated amount and how sure the bidders were in realising these savings, differed. The local public company estimated total synergetic savings of US\$ 17 million while the private company estimated them in a range between US\$ 11 million and US\$ 17 million. The private bidders were less sure of realising these investment savings, possibly because its dependence on other parties.

The legal organisation for the execution of the project as well as the responsibility for, and authority and control over, the execution: The major difference related to the legal organisation between the two proposals was the establishment of a new company versus an existing one. The liability structure of the existing local multi-utility was clear; in the private option it still had to be seen. A disadvantage of local company's proposal was the complete integration of almost all utility services into a single integrated company. This implied an extreme dependence of the government and the whole economy of the island on one utility concerning pricing and service delivery. Moreover, such integration implicated the continued acceptance of cross-subsidies from electricity towards water and sanitation. The private option was complicated as far as the transfer of assets was concerned. It required agreement on the water distribution part to be transferred to the newly created company. This proposed transfer would encounter some obstacles in implementation. In its accounting reports the local multi-utility put a claim on the water distribution assets of about US\$ 56 million as previous losses on the water distribution activities. If the island government wanted to transfer these assets, it could be expected that the public multi-utility would ask for repayment of these losses, slowing down the process substantially. Another difference was that in the local public option, control by the government is more direct, since the government owns the company, nominates its director and a commissioner is chair of the Board. In the case of the foreign private party the government is a minority shareholder and can only indirectly execute authority.

In sum, with respect to how the parties intended to internally organise themselves, both parties can be assessed as having a same level of compliance to the governmental references. The private party's intentions can however be assessed as more opportunistic, especially with respect to its legal organisation, and taking over of personnel. 


\subsection{How does the party intend to interact with external parties?}

The island government has to establish a facilitating environment in order to make the project successful. In view of the limited institutional capabilities of the island government, the smaller the demands of the bidder, the higher the proposal scored.

The conditions that are being demanded of the island government to guarantee the successful execution of the project: Due to the more intensive investment that the proposal of the private party envisaged at the beginning of the project, it is expected that the private party will need more support from the government in bridging the expected problems regarding disruption of life on the island by construction works. Moreover, the private party identified many conditions for the island government, of which several of them seemed very hard to satisfy. Especially, in view of the weak financial condition of the island government and the latent shortage of qualified civil servants, it can be predicted that these will form large obstacles in an implementation phase. Hence, the public option seemed the most practical choice here, although opting for the public local multi-utility in fact implies the creation of a large monopoly on the island. Hence, again the private party inhibits the most risk taking behaviour compared to the public party.

\section{Conclusion}

The assessment of the intentions of both bidders centred on two main questions, i.e. the extent to which the party took the freedom to deviate from the governmental references, and secondly the extent to which the intentions of the party were risky and innovative. With respect to the first question, it is clear that both bidders reacted similarly. Both parties based their intended strategies heavily on the existing documents and references provided by the government. Neither of them took the effort to deviate from these references, using their expertise and creativity, adding additional value to their proposals. With respect to the second question it is clear that the private party is more innovative, opportunistic and risk taking compared to the public company. The private company intended to make the largest investments, with a rapid connection policy, with the lowest leakage rates, with the cheapest external financing and the largest challenges towards its internal and external organisation.

However, the more aggressive strategy of the private bidder did not qualify them to also win the proposal. The evaluation result using the evaluation criteria gave the proposal from the public local company a competitive advantage over that of the foreign private party. The local company's proposal scored better on seven criteria, while the private party outscored the public party on only one criterion, and on two criteria, they approximately drew. It is interesting to notice that the theoretical maximal score (in the case of a perfect proposal) in the Multi-Criteria Analysis (MCA) would be 10,000 points. The 'winning' party scored only approximately $35 \%$ of the maximum possible score, and its winning margin over the private party's proposal was a rather modest $8 \%$ of the achieved score. Hence, an important confirmation provided by the MCA is that neither proposal achieved more than approximately one third of the possible total score. Neither of the proposals fully complied with the given Terms of Reference nor is of the professional level expected for proposals for a project of this size, importance and potential impact. 
As a conclusion to the article several observations can be made in sequence of the structure of the article as follows:

- the Caribbean region has an important challenge to face in addressing the currently lagging public infrastructures on the island

- $\quad$ private sector involvement as an alternative to public sector management will remain an important option for Caribbean governments to consider

- the decision process in weighing between the private and public option should be carefully constructed, taking the history into account, looking at the special institutional conditions and involving the stakeholders and even then there is no guarantee for success

- $\quad$ in the St. Maarten case a clear difference could be observed between the more aggressive, risky and opportunistic strategies of the private party and the more defensive behaviour of the public party.

Although from this one case obviously no generalisation is possible, the difference in intended strategies might point towards some ownership inherent qualities of both parties. In the terminology of Miles and Snow, publicly owned parties act more Defender like, while privately owned parties act more like a Prospector. Recognising that ownership of an operator may be associated with certain strategic typologies may help governments to align the extent of private sector involvement with their policy priorities.

\section{References}

Brdjanovic, D. and Gijzen, H. (2005) 'Challenges in achieving a sustainable water supply and sanitation services for small islands: the Caribbean perspective', Proceedings Aqua, 31 October 4 November, Cali, Colombia.

Brdjanovic, D., Schouten, M., Hes, E, Schippers, J., Kennedy, M., Trifunovic, N., Vojinovic, Z., Van der Steen, P., Von Münch, E., van Dijk, M.P., De Bruijn, R. and Gupta, J. (2005) Evaluation of the Proposals for an Integrated Sewage and Drinking Water System on St. Maarten, Vol. 1.

Boubakri, N. and Cosset, J. (1998) 'The financial and operating performance of newly privatised firms: evidence from developing countries', Journal of Finance, Vol. 53, pp.1081-1110.

Boyne, G.A. and Walker, R.M. (2004) 'Strategy content and public service organizations', Journal of Public Administration Research and Theory, Vol. 14, No. 4, pp.231-252.

Brown, W.A. and Iverson, J.O. (2004) 'Exploring strategy and board structure in non-profit organizations', Non-Profit and Voluntary Sector Quarterly, Vol. 33, No. 3, pp.377-400.

Crain, W.M. and Zardkoohi, A. (1978) 'A test of the property rights theory of the firm: water utilities in the United States', Journal of Law and Economics, Vol. 21, pp.395-408.

Dewenter, K. and Malatesta, P. (2001) 'State owned and privately owned firms: an empirical analysis of profitability, leverage and labour intensity', American Economic Review.

Donahue, J.D. (1989) The Privatization Decision: Public Ends, Private Means, Basic Books, Inc., New York, NY.

Grabowski \& Poort St. Maarten N.V. (1995) Basis Riolerings Plan St. Maarten.

Grabowski \& Poort, St. Maarten N.V. (1998) Ontwerp Eilandelijk Rioleringsplan St. Maarten $1998-2010$. 
Jerome, A. (2004) 'Privatisation and regulation in South Africa. An evaluation', 3rd International Conference on Pro-Poor Regulation and Competition: Issues, Policies and Practices, 7-9 September, Cape Town, South Africa.

Megginson, W., Nash, R. and Randenborgh, M. (1994) 'The financial and operating performance of newly privatized firms: an international empirical analysis', Journal of Finance, Vol. 59, pp.403-452.

Miles, R.E. and Snow, C.C. (1978) Organisational Strategy, Structure and Process, McGraw-Hill, New York.

Pargal, S. (2003) Regulation and Private Sector Investment in Infrastructure: Evidence From Latin America, Policy Research Working Paper 3037, World Bank, Washington.

Pinsent Masons (2006) Pinsent Masons Water Yearbook 2006-2007, Pinsent Masons, London.

Publius Ovidius Naso (43 B.C.) Ars Amatoria.

UNEP (1999) Assessment of Land-Based Sources and Activities Affecting Marine, Coastal and Associated Freshwater Environment in the Wider Caribbean Region, UNEP Regional Seas Reports and Studies No. 172.

Vickers, J. and Yarrow, G. (1991) 'Economic perspectives on privatisation', Journal of Economic Perspectives, Vol. 5, No. 2.

Ward, P.T., Duray, R., Leong, G.K. and Chuong, S.C. (1995) 'Business environment, operations strategy, and performance. Empirical study of Singapore manufacturers', Journal of Operations Management, Vol. 13, No. 2, pp.99-115.

World Bank (2005a) Achieving Environmentally Sustainable Tourism in the OECS Sub-Region, Report No. 31725-LAC, World Bank, Washington.

World Bank (2005b) A Time to Choose: Caribbean Development in the 21st Century, 26 April, Caribbean Country Management Unit, Poverty Reduction and Economic Management Unit, Latin America and the Caribbean Region. 